\title{
The Sydney Dance Music Scene AND THE GLOBAL DIFFUSION OF Contemporary Club Culture
}

\author{
Transforming Cultures eJournal, \\ Vol. 4 No 1 April 2009 \\ http://epress.lib.uts.edu.au/journals/TfC
}

\section{Ed Montano 1}

\begin{abstract}
The development of contemporary, post-disco dance music and its associated culture, as representative of a (supposedly) underground, radical subculture, has been given extensive consideration within popular music studies. Significantly less attention has been given to the commercial, mainstream manifestations of this music. Furthermore, demonstrating the influence of subculture theory, existing studies of dance culture focus largely on youth-based audience participation, and as such, those who engage with dance music on a professional level have been somewhat overlooked. In an attempt to rectify these imbalances, this paper examines the contemporary commercial dance music scene in Sydney, Australia, incorporating an analytical framework that revolves mainly around the work of DJs and the commercial scene they operate within. Given the increasingly global and corporate nature of the dance music scene, there is a sense that the music and culture are becoming less 'local' and more 'international', with this global movement affecting the identity and development of local scenes, the understandings and practices of those who are involved with these scenes, and the very definition of a 'scene' itself.

The ideas, opinions and interpretations of a selection of local DJs and other music industry practitioners who work in Sydney are central to the paper's analysis of DJ culture within the city. It is my intention to place the local scene in Sydney into some sort of wider cultural and global context, but at the same time to highlight what aspects of the scene give it a unique local identity. Being a scene that relies quite heavily on overseas dance culture, and indeed places a certain emphasis on the cultural value of overseas music and international DJs, it can be somewhat difficult for local DJs and producers to establish themselves, and thus a certain tension exists between the local and the global.
\end{abstract}

\section{Introduction}

This article examines the contemporary commercial dance music scene in Sydney, Australia, incorporating an analytical framework that revolves mainly around the work

\footnotetext{
${ }^{1}$ Ed Montano completed his PhD at Macquarie University in 2008.
} 
of DJs and the commercial scene they operate within. In using the terms 'dance music' and 'dance culture', I am referring to the 'commercial', DJ-played music that one can hear in such Sydney clubs as Home, The ArtHouse, Slip Inn, and Tank, and at various bars, pubs, festivals and events within the city area. Dance music has a central role not just in the culture of the city, but also socially and economically, and on a wider geographical scale. The article is intended to complement and add to analysis that has previously been conducted of Sydney, and Australian, dance music culture (examples being Murphie and Scheer, 1992; Homan, 1998; Gibson and Pagan, 2000; Brookman, 2001; Luckman, 2002; Brennan-Horley, 2007).

The ideas, opinions and interpretations of a selection of local DJs and other music industry practitioners who work in Sydney are central to the article's analysis of DJ culture within the city. My arguments and observations are based on ethnographic research I conducted in the Sydney dance music scene between 2002 and 2006. In addition to the requisite nights out clubbing, this research involved qualitative interviews with twenty-one people (DJs, journalists and promoters) conducted over a period between September 2004 and October 2005. All interviews were conducted 'one-on-one', as opposed to in groups, and took place in locations such as bars, coffee shops, and respondents' homes (Weber, 1999: 321). Furthermore, between September 2002 and December 2004, I was also a participant-observer, working at the Sydneybased specialist dance music store Central Station Records, and it was here I made contact with most of my interviewees, either directly, in the sense that they were customers of the store and so I came into regular contact with them, or indirectly through networks of contacts I managed to establish during my work at the store. While ethnographic research of this nature is not without problems (Thornton, 1995: 105-107), I believe this was the best methodology to employ for this particular project, and as Brennan-Horley notes, "what is clear is that detailed ethnographic research is required to understand the workforce and commercial dimensions of dance music culture" (2007: 126).

The article explores how the degree of 'global interaction' within dance music culture has generated certain mythologies and authenticities in regard to place. Certain cities and locations have been positioned as representing the point of origin for particular dance music styles, and this has subsequently impacted upon how dance music culture 
has developed specifically in Sydney. The geographical diffusion of contemporary dance music and culture around the world has created notions of certain scenes being 'behind' others, in regards to such things as music, technology, and fashions. This notion of diffusion is in part drawn from the work of Kong et al. (2006) who, in their article on creative industries discourses in Asia, note how these discourses have typically been influenced by debates in the North Atlantic, and thus

A classic diffusion model could be applied in order to trace how a particular assemblage of ideas (in this case of the creative economy) radiates out from centres of production elsewhere, eventually reaching Asian locations in turn (2006: 175).

Specific urban locations have come to be regarded as central to dance music history. For participants in Sydney's dance music scene, its distance from what are perceived as the centres of dance music culture (western Europe and the USA) has affected the development of the scene, and has impacted upon the ideals and authenticities that have become ingrained within the scene. So the theme of this article concerns the idea that within dance culture there is a kind of process that runs across international space that involves the social construction of some places as 'behind' others. This idea features significantly within the discourses that surround dance music culture in Sydney (and indeed dance scenes elsewhere in the world), but obviously there are numerous assumptions contained within these discourses, and so the case of dance music in Sydney can be explored as a way of critiquing these assumptions.

Dance music history is often traced through reference to specific geographical locations, such as the development of house music in Chicago, techno in Detroit, acid house in Britain, trance in Goa, and the Ibiza scene, although this is not to say that different dance scenes all have similar characteristics drawn from a handful of places of significance. Connell and Gibson make reference to this issue when they state:

Dance music and 'techno' musical forms in the 1990s have their own histories that tend to emphasise 'authentic' origins ... Yet, experimental electronic music has been part of musical scenes across many continents, where the relatively anonymous repetitive beats and instrumental grooves of UK or American tracks are heard and enjoyed not as part of a 'passive' act of listening to overseas artists, but as the sounds and signifiers of a sub-culture that exists in distinct ways in each locality (2003: 108). 
It remains the case that Australian dance music culture draws extensively on the sounds and styles of Europe and the USA. Apart from the music itself being foreign in origin, much of the surrounding culture and fashion of the Australian dance music scene is also drawn from overseas, so that, as Murphie and Scheer suggest, "house music in Australia is about constructing identities using borrowed or translated signifiers" (1992: 183). It is impossible to ignore the influence that international dance culture has had on the formation and development of the Sydney dance scene, and as Susan Luckman points out,

... the wider popularisation in Australia of dance music and events in the early 1990s was fuelled, and hence participant's [sic] expectations and styles informed, in large part by the European, especially British, experience. Whether it was through fashion magazines, the growing celebrity status of overseas DJs, the accessibility at a recorded level of overseas material, or people's own travel abroad, the mythic ethos of the increasingly mainstream British scene loomed large over many Australian's [sic] consumer expectations (Luckman, 2001a: 63-64; see also Brennan-Horley, 2007: 124-125).

While all the places mentioned above certainly have their place within dance music history, it does not follow that all other scenes simply follow the trends set by these places as the culture diffuses globally, and that participants in other scenes simply passively accept and absorb the music from these places, for as Kong et al. note, there are "... nuanced ways in which ideas travel, become popular and are mutated to suit local circumstances - or indeed are not absorbed" (2006: 176).

This idea of specific geographical locations or cultures being set up, rightly or wrongly, as authentic points of origin for particular styles can be found in other areas of popular music culture. The dominant narrative within hip hop culture emphasises black America as the source and origin of rap music, and positions other places as then 'following' trends and styles through subsequent global diffusion, when in reality there are diverse hip hop scenes throughout the world that fuse local and global characteristics into unique forms. As Mitchell highlights:

Hip hop and rap cannot be viewed simply as an expression of AfricanAmerican culture; it has become a vehicle for global youth affiliations and a tool for reworking local identity all over the world (2001: 1). 
Similarly, jazz has been associated with New Orleans, while punk is typically cited as originating in London and New York, to the extent that other places (for example, the Australian punk scene in the 1970s) have often been overlooked or sidelined. Yet because of the myths that have developed within popular music culture, this idea of places being put into a particular hierarchy has become quite prominent, and feeds into the way some places are constructed as 'ahead' or 'behind' others in a trend cycle. So the following discussion is intended to raise some ideas in regards to who might be behind the creation of such place-centred discourses within the Sydney dance music scene, and how these discourses develop.

With this in mind, I would suggest that it is participants within Sydney dance music culture who have constructed the city as being 'behind' the UK and the USA in fashion cycles, through such things as billing overseas DJs higher or placing prominence on their geographical origins in marketing material for club nights and festivals. This has become so pervasive within the scene that a perception has been created that equates overseas locations with the initial diffusion of contemporary sounds and styles, a perception that Sydney dance party promoters and participants continually 'buy into'.

I would suggest that this idea of Sydney as being 'behind' stems in part from the way promoters have always looked to the UK when staging parties and establishing venues. Many of the commercial dance clubs, events and club nights in Sydney today, such as Home, Sublime, Tank, and Chinese Laundry, were based, to a certain extent, on UK 'superclubs' such as Ministry of Sound, Renaissance, and Cream, employing extensive advertising campaigns, brand names and recognisable logos to promote their venues and nights. As Brennan-Horley notes, "mirroring developments in England, 'superclub' brands surfaced in Australia" (2007: 125). Sydney DJ Trent Rackus acknowledges the impact the opening of Home had on the Sydney scene, in that the size of the club and the financial support behind it were on a scale far greater than anything else in Sydney's clubbing landscape:

The scene changed a lot when Home nightclub got up and running. These were overseas investors who had plenty of money, and they started offering big money to international DJs which made it a lot harder for [the smaller promoters] to compete (Interview, 2004). 
So putting this emphasis on international DJs, and thus by extension international dance culture, raises this idea of the music and the culture diffusing from overseas locations. This can be traced further back in the history of the Sydney dance scene, in that it is widely acknowledged that the dance parties and raves that were put on in the late 1980s and early 1990s were based on UK models of the warehouse party, partly because they were put on by British backpackers or 'expats', which in turn can be seen as generating the perception in Sydney of Britain as one 'authentic' source of origin for dance music culture. Sydney DJ and electronic music performer Seb Chan acknowledges the influence British rave culture had on the developing rave scene in Sydney:

[The free party scene was] very similar [to the scene in the UK]. There were some local variants on all of that, like anywhere there's always going to be local variations. The whole rave thing, I guess, moved from the Hordern party scene here to rave as a result of British tourism. A lot of those early rave DJs were expats. People who had come out here and then stayed on... Sugar Ray, Phil Smart, all those people... (Interview, 2005).

\section{The impact of technology}

The Sydney scene exists around music imported from overseas, which, three or four years ago, could be seen, in part, as a result of the decline in vinyl production in Australia. Today, with the increasing use of the internet as the source from which DJs obtain most of their music, whether in the form of physical product (most likely to be CDs, as opposed to vinyl) or as digital downloads, it is becoming far easier to access music from all corners of the globe, which obviously has a direct impact upon the musical content of the scene in Sydney. In previous years, when DJs relied solely on vinyl, the time it took for this vinyl to reach Australia meant that the notion of the Australian dance music scene as being 'behind' its counterparts in the northern hemisphere was very much a part of the discourse that surrounded the scene. Yet this has now been almost entirely eradicated, given the immediacy in obtaining music that new technology facilitates, although interestingly, geographical distance still dominates the discourses of Sydney dance music culture, so that

... proximity and physical distance still matter in explaining the spreading popularity of ideas, despite the advent of new information and telecommunications technologies that were meant to overcome 'frictions 
of distance' and produce an immediacy in information flow through new technological-economic networks (Kong et al., 2006: 175).

The majority of this music originates from the USA and Britain. Yet this does not dictate that participants in the Sydney scene have a passive role as followers of trends and developments abroad. It is rather the case that its participants acknowledge the centrality of these two geographical locations to the creation and continued existence of dance culture, and therefore position the music that comes out of them as of significant cultural value. Dance music is not dismissed or rejected for not being local in origin, but rather it is accepted simply as a representation of 'dance culture' as a complete whole. Concerns of 'localism' and 'internationalism' may make themselves evident in media discourse around the scene, but for the DJs and the clubbers, such concerns are an irrelevance during the ritual of the 'night out'.

Obviously, the commercial availability, and indeed unavailability, of this music will impact upon the shape of the local scene. In this sense, it can be argued that the Sydney dance music scene is shaped and defined, in part, by the music that is imported into the city from abroad, and thus the decisions of record store owners and DJs in selecting this music have a direct impact upon the music that participants in the scene are exposed to. As such, the central tenets and ideologies of dance culture do not reside in notions of tensions between local product and imported product, but rather in unique and specifically local interpretations and articulations of a wider, globally diffused dance culture. As Sydney DJ Alan Thompson (who, prior to moving to Australia in 2004, lived and worked in the UK, and therefore is particularly well-placed to comment on the international scope of dance culture) highlights, the influence of the UK scene is felt not just in Australia, but all over the globe, and as he explains, this is of no major concern for most clubbers because of the fact the very nature of contemporary dance music and club culture is inherently global:

I think the dance music scene as it is today is completely imported, all around the world, from the UK. I do really believe that. Having DJed since 1990 and travelled all over the world, I've seen various countries change over the years, and what is predominant in that change is that the clubs themselves are marketing themselves, and their music policies, and the DJs, to what the UK does. You could stand in a club in Tokyo, in Montreal, in New York, or Singapore, or even Sydney, close your eyes and without knowing what is going on, you could be in a club in England. I do think that they do try to emulate what goes on in the UK, 
which is a good thing... The dance scene has a worldwide identity. I really believe that dance music is a world phenomenon, and we are all dancing to the same beat, but in different countries (Interview, 2005).

A few years ago, prior to the widespread use of the internet, the belief that the scene was temporally 'behind', in the sense that music that originated in the UK or US was already a few months old by the time it was imported into Australia on vinyl, was firmly ingrained within the Sydney scene, and indeed Australian dance music culture as a whole. In fact, such a scenario was typical of scenes all around the world, and the time-lag between the release of a record in one particular scene and its subsequent distribution around the world served to create, in part, an unbalanced and fractured international dance culture, with different scenes being at different phases in their development musically and stylistically. As Will Straw highlighted in 1991, "coexisting regional and local styles within dance music are almost always at different stages within their cycles of rising and declining influence" (1991: 381).

Yet the perception of the Australian dance scene as being 'behind' is somewhat unsupportable, given the rapid facilities and channels that now exist for the worldwide distribution of music through the development of the internet and digital download technology. It is in this sense that dance culture is becoming more 'international', with geographically disparate scenes being closer in their stages of musical development than ever before. With this shorter timeframe for accessing and obtaining music, it would seem Straw's suggestion that, "the availability of vinyl has become one of the important ways in which national musical cultures remain differentiated" (2002: 175), is becoming less applicable for dance culture. As DJs rely less on the physical commodity of vinyl, and make increasing use of digital media, the international interconnectedness of dance culture will become even more developed. Sydney DJ and electronic music performer Seb Chan explains how certain practices intrinsic to DJ culture and the use of vinyl are being carried over into the use of digital forms, such as the notion of the 'dubplate', in the process breaking down the stylistic boundaries and markers that used to divide scenes in different geographical locations:

I know lots and lots of DJs who are getting MP3 dubplates, effectively, via peer-to-peer, officially from artists, directly to play out at parties. It is totally bypassing borders, as such, because it is possible now. So it is hard to say now that these scenes have boundaries. They don't have 
national borders nowadays, but they certainly did before the ability to transmit music became so easy (Interview, 2005).

This idea of a 'global network' of dance scenes is reinforced by the increasing use of the internet, as opposed to the more traditional form of the retail record store, as the source from which most DJs purchase their music. Several of the DJs I interviewed explained how they are now bypassing the traditional 'bricks and mortar' local record store in favour of both websites of overseas physical stores (such as Perfect Beat in L.A.) and digital download websites (such as beatport.com), in order to obtain the freshest and newest tracks. I know from my experience in music retail that it can often be easier for a customer to obtain music that has yet to be released in Australia from an overseas store, rather than attempt to order it via their local store, either because the supplier and distribution networks a store deals with cannot source that particular release, or because there are delays in ordering and shipping. Furthermore, with the increasing audio quality of digital downloads, it is making more financial sense to avoid paying for imported 12-inch vinyl, which typically retails in Australia for approximately $\$ 20$, and which would probably get you the original track and three remixes, and instead make use of the internet. As Sydney DJ Paul Goodyear highlights:

In the last couple of weeks I've just started downloading stuff from websites such as beatport.com, where you pay US\$1.49 and you're able to access [a particular] track. This site [features] a lot of new producers who put their music up on the site, and it won't be released for probably a couple of months. So for less than two Australian dollars per track, you've got something that's way ahead of release, the quality is fantastic, and it's much cheaper than spending twenty bucks on a piece of vinyl (Interview, 2005).

The development of the internet has thus created a 'global distribution network' within dance music culture, making it easier to buy music from different countries and easier for music to be distributed around the world. Discussing the formats he uses when DJing, Sydney DJ Alex Taylor acknowledges the way technology has made it easier and cheaper to obtain the latest music from around the globe, so that he now sources most of his music as downloads from the internet, which he then puts on to $C D$, as opposed to purchasing vinyl from record shops in Sydney, while he also highlights how technology has made it easier for DJs and producers in different geographical locations to share and distribute music: 
I use both [vinyl and CDs], although I'm using more CDs now than I used to, probably sixty-five to seventy percent CDs now. It's just so much easier and quicker. I'll get [music] from traxsource.com. It is US\$1.99 for a track, but you'd pay AUS $\$ 17$ or $\$ 18$ here for it. You get it straight away, and then I'm seeing it [in record shops here] three weeks later... A lot of those record companies [that sell their product on the Internet] actually still make slightly more money than they would have if they'd actually had to press it all up on vinyl. So they're making the same amount of money, but are able to sell it for less, so they're cutting out some middleman somewhere... I don't think vinyl will always be around. I never thought I would say that, and it's been around a lot longer than people said it would be, they said it was dead a long time ago, but so many people I talk to are just all about CDs. If you're a producer/DJ, you finish a track, and instead of bothering to put it out on to vinyl, you're just giving it out to all your mates on $\mathrm{CD}$ as a promo. It is so quick and easy. You can even share it with instant messaging now. They've done [a track] in London and can send it to you in Sydney straight away. You've got it that night (Interview, 2005).

Yet for all this discussion of how technology is bringing geographically separate scenes closer together and eroding the sense that Australian dance music culture 'lags behind' British and American scenes, we cannot simply take the perspective that there is a unified global dance music culture that transcends national boundaries and divisions. There is a certain unrealistic idealism contained within such a perception, and also a demonstrative lack of understanding of the way locality and identity serve to create place-specific dance scenes that have unique operational practices and infrastructures. Describing local dance culture as simply imported does, in turn, provide an overly simplistic and narrow interpretation of the specifically local developments and progressions in Sydney's dance scene. As Kong et al. note, “internationalising discourses do travel effectively, but are inflected by place-specific geographies" (2006: 181).

\section{The festival factor}

Something which has served to emphasise the uniqueness of the Sydney dance music scene in recent years, but at the same time has contributed to the sense of Sydney being constructed as 'behind' other scenes, is the recent surge in popularity of daytime dance music festivals. As dance culture has become an increasingly commercial enterprise, there has been the development of a party circuit that focuses on large, annual, festivallike events, as opposed to the weekly nights of club culture, with these events being 
staged away from the traditional environment of the club, at locations such as parks and other open public spaces, and being held during the day, rather than the more traditional night-time and early-morning hours when club culture is most typically experienced. Examples of such parties that are specific to the Sydney scene include the one-day dance music events put on by Fuzzy during the spring and summer months, such as Field Day (an annual dance music event held in Sydney's Domain park area on New Year's Day, which is one of the key events in the Sydney dance music calendar, with a capacity of 20,000), Parklife (an annual dance music event held over one day in Sydney's Moore Park, which in 2005 took place on Sunday October 2), and Harbourlife (an annual dance music event held over one day in Sydney's Fleet Steps area, adjacent to the Royal Botanic Gardens, which in 2005 took place on Saturday November 26). These events have become increasingly popular over the past five years, and have, in part, initiated a shift away from night-time clubbing and more towards daytime dancing, with extensive DJ line-ups, and the more popular international DJs promoted as headline acts over numerous local DJs. This billing of overseas DJs higher than their local counterparts, and placing emphasis on their geographical origins in marketing material, most certainly contributes to the construction of mythologies in regard to place and dance music, and has subsequently generated a perception within the Sydney dance music scene that the fact a DJ is from London or New York somehow makes him or her more culturally credible or more highly skilled than a DJ from Sydney.

With his company Fuzzy, John Wall is responsible for staging Field Day, Parklife, Harbourlife, and other dance parties in Sydney. It can be argued that the emphasis these events place on international acts and DJs has led to the mythologizing of overseas dance culture, and has subsequently led to Sydney being perceived as 'behind' other dance scenes. Discussing this idea, Wall highlights the educational value of international DJs, describing how they help to further the knowledge and understandings clubbers have of dance culture as a global phenomenon, while he also acknowledges the appeal for clubbers that is inherent within the irregularity of international DJ performances:

Some people say that they like to see an international DJ purely for the reason that they know they are not going to see them for a year, so they get really excited about that DJ, as opposed to a local DJ. They might really like the local DJ, but they can see him any time... At the same time, a lot of people think that if a DJ is from somewhere else they are 
better, and they don't even think about it logically. There have been discussions, like on inthemix, ${ }^{2}$ or whatever, where people have just said, "Well obviously international DJs are better", and things like, "Well that's why Fuzzy put on international DJs at their parties, because they are better", and I've gone on there and said, "Well it's not as simple as that". A lot of them are big names because they have produced some kind of music. A lot of them may represent some kind of scene which is bigger somewhere else than it is here. If you get some techno DJ from Detroit, they are representing something that comes from a certain place, and so there's a real reason to have them come here. Maybe not now, but when that kind of music was not as well distributed around the world. There are areas that develop a particular sound, [so] it makes a lot of sense to bring somebody who people have heard of, that associates with that sound, and bring us their version of how they play that kind of music where they come from, and there's a lot of value in that because it expands your idea of what's going on in the world (Interview, 2005).

At the same time, however, despite placing this value on international DJs, Wall also explains how he in no way subscribes to the opinion that international DJs are in some way better than local Sydney DJs, and he describes how such an opinion is an erroneous judgement held most typically by clubbers:

I really completely reject the idea that DJs from other countries are better than DJs from Australia, and on aforementioned discussions on inthemix, I said you've got to understand that a lot of these international DJs come out here and are really impressed by the standard of the DJing in Sydney... and the reply to that on inthemix was, "It just shows that you're bringing out crap internationals", and it doesn't even matter if that's true. The fact is, they are totally ignoring the possibility that a DJ who's a big deal from overseas could think that our local DJs are good. Not everybody is like that, and plenty of people have got ears, and can hear and understand that it's not just about overseas equals better... people talk about cultural cringe, and it's very real. It's not as bad as it was when I was young, but nevertheless, because we are a long way away, and because most people going out to clubs are eighteen to twenty-five, haven't necessarily had the opportunity to go overseas, live there for a couple of years and really get involved in a similar scene, so they kind of assume that it's probably better, or bigger, or more sophisticated, or whatever, and that therefore the DJs are more skilful, it's more competitive, more music is available there, and so on and so on and so on... It's always a bit hard to get people to really give local acts and DJs the credit they deserve, and every now and then somebody makes it, like Kid Kenobi has (ibid.).

\footnotetext{
${ }^{2}<$ http://www.inthemix.com.au $>$ is a website dedicated to dance music culture in Australia, with news, reviews, email forums, photo galleries, online ticket sales, and club listings all featured on the site, and with each state capital city within Australia (Sydney, Canberra, Melbourne, Brisbane, Adelaide and Perth) receiving focus, so that the site caters specifically for the scenes at the local urban level, as well as the national level. The site name is typically abbreviated by those within the scene to 'inthemix'.
} 
The local dance music media can also be seen as partly contributing to this perception of overseas DJs and dance music, and in turn constructing a geographically-based trend cycle, positioning the Sydney scene as 'behind' overseas scenes, so that Sydney is seen to 'follow' the sounds and styles that emanate, through a process of global diffusion, from scenes outside of Australia. As Sonia Sharma (editor of $3 D$ World, a local dance music street press publication) explains, the emphasis on international DJs in the Sydney scene is largely perpetuated by the local media, providing an example of how the media directly affect the shape and content of music scenes, and she highlights how, despite the popularity of events that have extensive international DJ line-ups, this emphasis is not always shared by the clubbers themselves:

I think there is [an over-emphasis on international DJs] by, perhaps wrongly, the media, which does include the publication I work for, and by promoters. The interesting thing is, we actually ran a signing area at Parklife and at a few other events. It's something we've just started doing, and what it involves is having the international DJs come down, and meet and greet with the public, and the amazing thing that we found was so many punters coming up saying, "Why don't you have local DJs signing?", and I think, for the punters, they realise... We continually get reviews that state, "' $\mathrm{X}$ ' international came out to play, but ' $\mathrm{Y}$ ' local support put on a much better set". I think the product in Australia, the DJing, is probably on par with an international level, but the emphasis is still on those big names (Interview, 2005).

Dance culture is very much a culture that is understood, articulated and explored on an international level, and thus every scene is part of the international flow and diffusion of information and music. Yet at the same time, a scene such as Sydney can be said to be less self-reliant and less self-sustaining than, for example, the dance scene in London, in that Sydney relies much more on the international traffic of DJs and music to give shape and definition to its dance scene. This is in part due to its relative marginality in the production of dance music. There is a definite sense, and acceptance on the part of DJs, that the Sydney scene is very much an imported version of dance culture in the UK, the US and Europe. Sydney DJ Trent Rackus claims the scene in Sydney

$\ldots$ is completely influenced by other territories. It's all because we don't have enough people producing music down here to create individual sounds. You don't hear of Australian trance or Australian garage or Australian breaks... there are Australian artists making breakbeat music, but it is music that's heavily influenced from other territories... anything that gets spat from a producer's studio from Australia, all the elements and the ingredients are imported from overseas (Interview, 2004). 
This lack of producers thus dictates that the scene relies heavily on imported music, although this has not constrained the growth of the scene in the city. For Sydney DJ Stephen Allkins, Sydney definitely has its own unique dance scene, and as he explains, the way the city was isolated from British and US dance scenes, at least during the initial stages of the development of dance music, actually served to enhance this uniqueness as the scene progressed and developed:

Every city in the world has a distinct scene. Even if I travelled from Sydney to Brisbane or Sydney to Melbourne, let alone to an international city, it's different, because every city in the world has a personality, and I don't think music is any different. Yes, definitely, Sydney has a personality, but so does London, and so does Paris, and they are not the same. As far as us adopting and all that sort of bullshit, we were... Infusion, Itch-E and Scratch-E, Robert Racic... we were doing stuff in the 1980s. We didn't wave flags, and just got on and did it, and it was incredibly ahead of its time. If you listen to early Itch-E and Scratch-E albums now, producers weren't doing it in England, they were still doing piano-based house, whereas in Australia, because we were so isolated, we didn't need references... I lived in New York in 1988. Nobody could mix records, and I'd been mixing records for eight years. Being kept in the 'back' doesn't mean that we're sort of the poor cousin (Interview, 2005).

Allkins identifies a perception that continues to run throughout the Sydney dance music scene, and it is a significant comment, as it highlights the idea of cultural diffusion across geographical space and the assumption that has developed within Sydney, which is that its distance from other dance music scenes has somehow limited or restrained its development. Yet as Allkins points out, this has not really been the case, but the perception that Sydney's geographical detachment somehow means its dance scene is less culturally credible or significant remains, and seems to be firmly embedded, within Sydney dance music culture.

Tracing the historical development of the Sydney dance scene from gay culture, through rave culture, and on to club culture, it becomes apparent that, while the influence of British, and to a lesser extent US, dance culture has played, and continues to play, a significant role in this development, it is through the work of DJs and promoters that the Sydney scene has taken on its own identity. While contemporary dance music culture is most certainly a global culture, it does not follow that it is consumed and experienced in a globally shared manner. The Sydney scene, and indeed Australian dance culture as a 
whole, has traditionally struggled with its supposed secondary position below the dance scenes of the UK, Europe and the USA, in part a result of its reliance on imported vinyl, and the lack of a sizeable and supportive dance music industry infrastructure. Dance music and DJs from the northern hemisphere still exert a significant influence over the Sydney scene, and will do so for as long as the scene's participants continue to associate the global diffusion of dance music with a hierarchy of place.

\section{Bibliography}

Bennett, A. (2000) Popular Music and Youth Culture: Music, Identity and Place. London: Macmillan.

Bennett, A, and Peterson, R.( eds.) (2004) Music Scenes: Local, Translocal, and Virtual. Nashville: Vanderbilt University Press.

Bidder, S. (2001) Pump Up The Volume: A History of House. London: Channel 4 Books.

Brennan-Horley, C. (2007) "Work and play: Vagaries surrounding contemporary cultural production in Sydney's dance music culture". Media International Australia 123:123-137.

Brewster, Bill, and Broughton, F. (2000) Last Night a DJ Saved My Life: The History of the Disc Jockey. London: Headline.

Brookman, C. (2001) "“Forever Young': Consumption and Evolving Neo-tribes in the Sydney Rave scene". BSc Thesis, Geosciences, University of Sydney, Sydney.

Cohen, S. (1999) "Scenes". In Key Terms in Popular Music and Culture, edited by B. Horner and T. Swiss. Oxford: Blackwell.

Connell, J, and Gibson, C. (2003) Sound Tracks: Popular music, identity and place. London: Routledge..

Fairley, J. (2001) The 'local' and 'global' in popular music. In The Cambridge Companion to Pop and Rock, edited by S. Frith, W. Straw and J. Street. Cambridge: Cambridge University Press.

Fikentscher, K. (1991) Supremely clubbed, devastatingly dubbed: Some observations on the nature of mixes on 12-inch dance singles. Tracking: Popular Music Studies 4 (1):9-15.

(2000) "You Better Work!" Underground Dance Music in New York City. Hanover: University Press of New England.

Frith, S. Straw,W. and Street,J. (eds.) (2001) The Cambridge Companion to Pop and Rock. Cambridge: Cambridge University Press.

Gibson, C. (1997) Subversive Sites: Rave, Empowerment and the Internet 1997 [cited 23/09/2003. Available from <http://www.snarl.org/youth/chris1.pdf $>$ ]

(1999) Subversive sites: rave culture, spatial politics and the internet in Sydney, Australia. Area 31 (1): 19-33. 
(2001) "Appropriating the Means of Production: Dance Music Industries and Contested Digital Space". In Free NRG: Notes from the edge of the dance floor, edited by G. St. John. Altona: Common Ground.

Gibson, C. and Pagan, R. (2003) Rave culture in Sydney, Australia: mapping youth spaces in media discourse 2000 [cited 15/08/2003. Available from http://www.snarl.org/youth/chrispagan2.pdf]

Haslam, D. (1997) DJ Culture. In The Clubcultures Reader, edited by S. Redhead, D. Wynne and J. O'Connor. Oxford: Blackwell.

(2001) Adventures on the Wheels of Steel: The Rise of the Superstar DJs. London: Fourth Estate.

Hayward, P. (ed.) (1992) From Pop to Punk to Postmodernism: Popular Music and Australian Culture from the 1960s to the 1990s. Sydney: Allen \& Unwin.

Hebdige, D. (1979) Subculture: The Meaning of Style. London: Methuen.

Hesmondhalgh, D. (1996) "Flexibility, post-Fordism and the music industries". Media, Culture and Society 18:469-488.

(1997) The cultural politics of dance music. Soundings 5: 167-178.

(1998) The British dance music industry: a case study of independent cultural production. British Journal of Sociology 49 (2): 234-251.

Homan, S. (1997) "Solidarity and sedition". Perfect Beat 3 (3): 90-94. (1998) “After the law". Perfect Beat 4 (1):5 6-83.

Horner, B. (1999) "Discourse". In Key Terms in Popular Music and Culture, edited by B. Horner and T. Swiss. Oxford: Blackwell.

Kong, L. et al. (2006) "Knowledges of the creative economy: Towards a relational geography of diffusion and adaptation in Asia". Asia Pacific Viewpoint 47 (2):173-194

Langlois, T. (1992) "Can you feel it? DJs and House Music culture in the UK". Popular Music 11 (2): 229-238.

Luckman, S. (1998) "Rave Cultures and the Academy". Social Alternatives 17 (4):4549.

(2000) "Mapping the Regulation of Dance Parties". Journal of Australian Studies (64):217-223.

(2001a. What are they raving on about? Perfect Beat 5 (2):49-68.

(2001b) "Practice Random Acts: Reclaiming the Streets of Australia". In Free $N R G$ : Notes from the edge of the dance floor, edited by G. St. John. Altona: Common Ground.

(2002) "Party People: Mapping Contemporary Dance Music Cultures in Australia". PhD, University of Queensland, Brisbane.

Malbon, B. (1999) Clubbing: Dancing, ecstasy and vitality. London: Routledge.

Marston, S. (2000) The social construction of scale. Progress in Human Geography 24 (2): $219-242$.

Mitchell, T. (1998) Australian hip hop as a 'glocal' subculture [cited 21/09/2003. Available from http://www.snarl.org/youth/tonym2.pdf] 
(ed.) (2002) Global Noise: Rap and Hip-Hop outside the USA. Middletown: Wesleyan University Press.

Murphie, A. and Scheer, E. (1992) "Dance parties: capital, culture and simulation". In From Pop to Punk to Postmodernism, edited by P. Hayward. Sydney: Allen \& Unwin.

Park, M. and Northwood, G. (2003). Australian Dance Culture 1996 [cited 05/08/2003. Available from http://www.snarl.org/texts/features/dancecult2.htm]

Poschardt, U. (1998) DJ Culture. London: Quartet Books.

Reynolds,S. (1998) Energy Flash: A Journey through Rave Music and Dance Culture. London: Picador.

(1999) Generation Ecstasy: Into the world of techno and rave culture. New York: Routledge.

Rietveld, H. (1998) This Is Our House: House music, cultural spaces and technologies. Aldershot: Ashgate.

Solowij, N. Hall,W. and Lee, N. (1992) "Recreational MDMA use in Sydney: a profile of 'Ecstasy' users and their experiences with the drug". British Journal of Addiction (87):1161-1172.

Straw, W. (1991) "Systems of Articulation, Logics of Change: Communities and Scenes in Popular Music". Cultural Studies 5 (3): 368-388. (2002) "Value and velocity: the 12-inch single as medium and artifact". In Popular Music Studies, edited by D. Hesmondhalgh and K. Negus. London: Arnold.

Thornton, S. (1990) "Strategies for reconstructing the popular past". Popular Music 1 (9):87-95.

(1994) "Moral Panic, the Media and British Rave Culture". In Microphone Fiends, edited by A. Ross and T. Rose. London: Routledge.

(1995) Club Cultures: Music, Media and Subcultural Capital. Cambridge: Polity.

Weber, T. (1999) "Raving in Toronto: Peace, Love, Unity and Respect in Transition". Journal of Youth Studies 2 (3): 317-336. 